Original Research Article

\title{
Good old pap smear towers over the latest LBC for cervical screening: a study in a rural teaching institute of Tamil Nadu, India
}

\author{
R. Gowri Sankar', R. Thamil Selvi², K. Anbu Lenin ${ }^{3}$, M. Poornima ${ }^{4}$ \\ ${ }^{1}$ Dr. R. Gowri Sankar, Assistant Professor, ${ }^{2}$ Dr. R. Thamil Selvi, Professor and Head, ${ }^{3}$ Dr. K. Anbu Lenin, Associate \\ Professor, ${ }^{4}$ Dr. M. Poornima, Tutor; above authors are affiliated with Department of Pathology, Vinayaka Missions \\ Kirupananda Variyar Medical College and Hospital, Salem, Tamilnadu, India
}

Corresponding Author: Dr. K. Anbu Lenin, Associate Professor, Department of Pathology, Vinayaka Missions Kirupananda Variyar Medical College and Hospital, Salem (TN) India. E-mail-dranbulenin@gmail.com.

\begin{abstract}
Introduction: Cervical cancer is the second most common cancer among Indian women and the fourth most frequent cancer in women across the globe. Though effective screening programmes are available, its role in effective prevention in a developing country like ours still remains an unanswered question and the probable reason behind this could be the difficulty in adopting liquid-based cytology (LBC) as the main screening program ahead of conventional pap smear (CPS). Aims and Objectives: This study was performed with an objective to analyse and interpret the samples by both CPS and LBC and to compare the both so as to find out the possibility of implementing LBC in a rural teaching institute of Tamilnadu like ours. Materials and methods: This was a prospective observational study which includes sample of 100 women who have attended the gynaecological outpatient department (OPD) of Vinayaka Missions Kirupananda, Variyar Medical College and Hospitals, Salem, Tamil Nadu. The slides were interpreted by two independent cytopathologists based on The Bethesda System and the results were analysed statistically. Results: The youngest patient was 19 years and the oldest was 68 years old. The most common age group in the study is $4^{\text {th }}$ decade. The commonest clinical presentation was discharge per vaginum (PV). Screening time was less with LBC which also showed cleaner background compared to CPS. Other parameters like organisms and epithelial cell abnormalities were detected in both CPS and LBC. Conclusion: Even though LBC was few steps above CPS while considering the smear background and time taken to screen the slides, CPS still remains the better among the two in our setup taking into consideration the cost efficacy it provides which is the main factor for the population in our rural setup.
\end{abstract}

Keywords: Conventional pap smear, Liquid based cytology, Rural Tamilnadu

\section{Introduction}

Cervical cancer is a public health problem in developing countries like India, which alone accounts for one quarter of the worldwide burden of cervical cancer $[1,2]$. As per World Health Organization, more than 30000 women die of cervical cancer each year and the alarming fact is nine out of ten women who die are in poor countries, which means some of the most vulnerable women are dying unnecessarily because each death can be prevented [3].

The idea of screening for early detection of cancer was accepted in the $1920 \mathrm{~s}$ after the development of exfoliative cytological techniques initiated through the work of Babes [4] and Papanicolaou [5].

Manuscript received: $1^{\text {st }}$ September 2019

Reviewed: $11^{\text {th }}$ September 2019

Author Corrected: $16^{\text {th }}$ September 2019

Accepted for Publication: $21^{\text {st }}$ September 2019
In 1941 George Papanicolaou demonstrated a test for the early detection of cervical cancer, contributing towards the creation of screening programs $[6,7]$. The first cervical cancer screening clinics were established in the 1940s [8]. The pap test is considered by many to be the most cost-effective cancer reduction program ever devised [9]. However, limitations of CPS such as suboptimal smears with insufficient squamous cells, presence of obscuring blood, dense inflammation and thick smears with overlapping epithelial cells reduce its sensitivity to as low as $50 \%$ with rise in false negativity rate ranging between $14 \%$ and $33 \%$ [10,11,12]. Liquid based cytology which is widely practiced in the developed countries was developed to improve the diagnostic reliability of Pap smears by reducing the number of inadequate smears and false negativity rate as well as allowing some important tests like Human papilloma virus testing to be carried out $[10,13]$. 


\section{Original Research Article}

Although there is sufficient western literature on LBC, the studies from India comparing CPS and LBC techniques are sparse. Moreover, there have been conflicting results with regard to the quality of LBC results $[14,15]$. Also to the best of author's knowledge the comparison study between CPS and LBC techniques in a rural setup of Tamilnadu like ours are very scant. Hence this study was undertaken to evaluate the samples using both CPS and LBC and thereby analyse and compare the findings of both to find out the limitations and advantages of CPS and LBC respectively so as to find out the productive gain of LBC in our hospital. One of the mainstays of this study is to find out whether the cost efficacy provided by CPS is superior to the advantages of LBC or vice-versa.

\section{Materials and Methods}

Study place: The study is conducted in Department of Pathology, Vinayaka Missions Kirupananda Variyar Medical College, Salem, Tamil Nadu.

Study type: This is a prospective study.

Study duration: The study duration was until the desired sample size of 100 is reached.

Inclusion criteria: A total of 100 samples of CPS and LBC that were received in Department of Pathology. All the women in the reproductive age group as well as perimenopausal group were included.

Exclusion criteria: All the women who were unmarried or not co-operative.

Study conduct: The study was a prospective study.

Sample size: This study included 100 samples, one for CPS and one for $\mathrm{LBC}$, that were received in the department of pathology with detailed clinical information from the randomly selected patients who have attended the gynaecology OPD of our hospital, with various complaints. The CPS smears were subjected to routine standardised processing and staining as per the protocol. The LBC samples were processed as per the protocol of the company that provided the kit. Many parameters were analysed on both the samples using microscope based on The Bethesda System and the observations were interpreted by two independent cytopathologists and recorded.

Statistical analysis: Data's were collected and analysed.

\section{Results}

A total of 100 samples were studied in detail. The youngest and the oldest patient in our study were 19 and 68 years respectively. The most common age group for whom the smear was taken belong to the fourth decade comprising of 38 out of 100 cases, followed closely by less than 30 year age group that includes 31 out of 100 cases. (Table-1) The mean and the median age of our study were 37 and 36 years respectively.

Table-1: Age group

\begin{tabular}{|c|c|}
\hline Age group & Percentage (n=100) \\
\hline$<30$ & 31 \\
\hline $31-40$ & 38 \\
\hline $41-50$ & 21 \\
\hline$>50$ & 10 \\
\hline
\end{tabular}

The patients presented with various clinical presentations among which the most common presentation was discharge per vaginum (46\%) followed by lower abdominal pain (42\%). Some of them presented with irregular menses as well as some with post coital bleeding (Table-2).

Table-2: Clinical presentation

\begin{tabular}{|c|c|}
\hline Clinical manifestation & Percentage (n=100) \\
\hline Discharge PV & 46 \\
\hline Lower abdominal pain & 42 \\
\hline Post coital bleeding & 11 \\
\hline Irregular menstruation & 21 \\
\hline
\end{tabular}

A total of seven parameters were compared between CPS and LBC (Table-3) so as to find the better one for our setup. The first parameter was the time taken to screen the entire slide. Though it is subjective the average screening time for a CPS smeared slide was 6 to 7 minutes whereas the same for LBC smeared slide was 3 to 4 minutes thereby proving that CPS is more time consuming than LBC and this advantage of LBC will be very useful particularly during mass screening programs.

Pathology Update: Tropical Journal of Pathology \& Microbiology Available online at: www.medresearch.in 720 | P a g e 


\section{Original Research Article}

As far as the adequacy of smears are considered there is no much significant difference between the two in our study as only 5 out of 100 cases were unsatisfactory for evaluation in CPS and 3 out of 100 cases in LBC preparation. This very minimal difference can be attributed to the sampling technique also. The most common reason for unsatisfactory smear is insufficient cell count in both CPS and LBC and then only the inflammation and haemorrhage obscuring the epithelial cells come to the picture. By taking into account the inflammatory background, again CPS and LBC did not show much difference as shown in the Table-3. Both CPS and LBC picked up the organisms well and the shift in flora was seen in 6 out of 100 CPS cases whereas LBC did pick up only 5 out of 100 cases.

The same thing applies for candidial forms also because CPS picked up candida in hyphae forms in 3 slides in slight contrast to LBC which picked up only 2 cases. Finally the most important thing, the epithelial cell abnormalities were compared between the two and to our surprise CPS was better than LBC but in a very mild manner. LBC picked up a total of 8 cases whereas CPS picked up 9 cases. Again this can be due to insufficient sample or non-representation of that area because of the sampling technique or may be due to more number of younger females ( $<45$ years) screened. Also the fragile nature of atypical cells would have made them get easily destroyed during LBC processing which can also be attributed to the low atypical cell pick up of LBC.

Table-3: Comparison of parameters between CPS and LBC

\begin{tabular}{|l|c|c|c|}
\hline Parameters & & CPS & LBC \\
\hline Screening time & & $6-7$ minutes & $3-4$ minutes \\
\hline Satisfactory smear & & $95 / 100$ & $97 / 100$ \\
\hline Unsatisfactory smear & & $05 / 100$ & $03 / 100$ \\
\hline Inflammatory background & & $77 / 100$ & $72 / 100$ \\
\hline \multirow{2}{*}{ Organisms } & Shift in vaginal flora & $06 / 100$ & $05 / 100$ \\
\cline { 2 - 4 } & Candidial forms & $03 / 100$ & $02 / 100$ \\
\hline \multirow{3}{*}{$\begin{array}{l}\text { Epithelial cell } \\
\text { abnormalities }\end{array}$} & LSIL & $03 / 100$ & $03 / 100$ \\
\cline { 2 - 4 } & ASCU-S & $04 / 100$ & $03 / 100$ \\
\cline { 2 - 4 } & HSIL & $01 / 100$ & $01 / 100$ \\
\cline { 2 - 4 } & ASC-H & $01 / 100$ & $01 / 100$ \\
\hline
\end{tabular}

Microscopic images

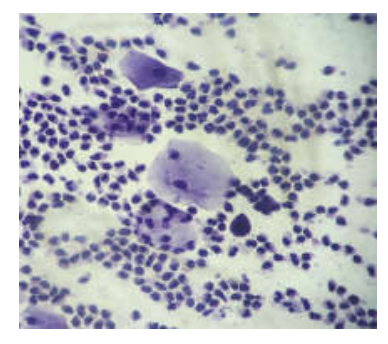

Fig-1: CPS - Inflammatory smear (H\&E)

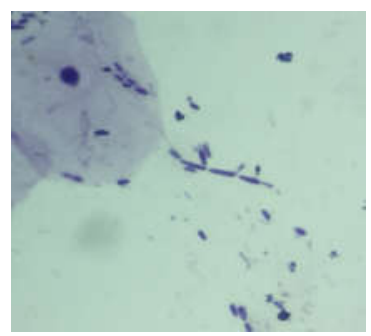

Fig-3: CPS - Candida organism (H\&E)

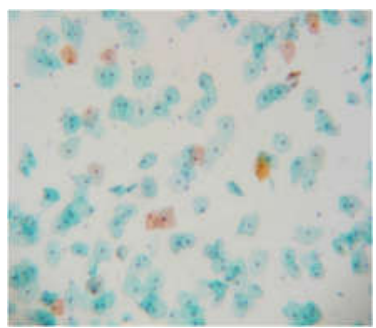

Fig-2: LBC - NILM (clean background)

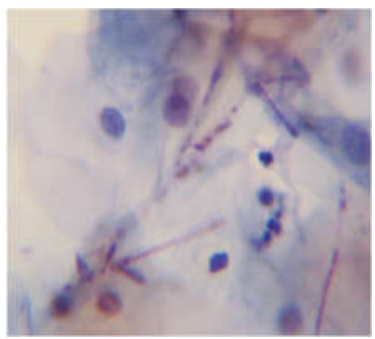

Fig-4: LBC - Candida organism 
Original Research Article

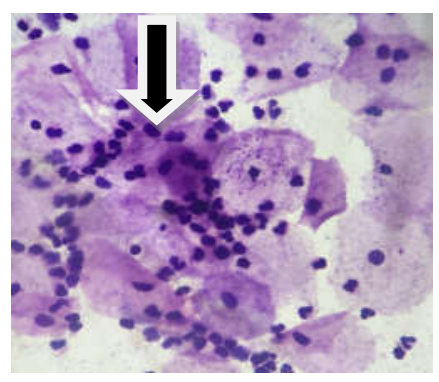

Fig 5: CPS - Bacterial vaginosis-clue cells (H\&E)

\section{Discussion}

Cancer is one of the leading causes of adult deaths worldwide and around 8 million people die of cancer every year [1]. Cervical cancer is one of the leading causes of cancer mortality accounting for nearly $17 \%$ of all cancer deaths among women aged between 30 and 69 years. It is estimated that cervical cancer will occur in approximately 1 in 53 Indian women during their lifetime compared with 1 in 100 women in more developed regions of the world [2]. Cervical cancer is the second most common cancer among women in India [16]. Prevention and early diagnosis are major factors in reducing morbidity and mortality resulting from neoplasia. [17]. Cytologic screening programs have led to a large decline in cervical cancer incidence and mortality in developed countries. However it remains largely uncontrolled in high risk developing countries because of ineffective or no screening [18]. In fact around $80 \%$ of the cases occur in developing countries and just $20 \%$ in developed countries [19].

The reasons for this high burden of cervical cancer in India is due to poor living standards, high HPV prevalence and of course due to lack of screening [20]. There are few statements stating that the major registries have shown a decreasing trend of cervical cancer, however the decrease was very small. In India, an organized mass screening program for early detection of cervical cancer is not in practice; hence this decrease cannot be attributed to screening [21]. There is a study which says that cervical cancer incidence rates are an underestimate for India possibly due to an under diagnosis of cervical cancer cases in rural areas and among impoverished women and also due to non-inclusion of subclinical cervical cancers in routine hysterectomy specimens not subjected to histopathology, which is a common practice in many parts of India [22]. Pap smear is a very important and useful method for cervical cancer screening. Globally, efforts to prevent the disease include screening women using Pap smears and treating precancerous lesions. Impressive results have been achieved in reducing cervical cancer incidence and mortality in some developed countries by Pap smear screening. Cervical cancer incidence can be reduced by as much as $90 \%$ where screening quality and coverage are high [23].

However, in developing countries - where approximately $80 \%$ of all new cases occur - many women have never had a Pap smear. Proper implementation of screening programs is essential to reduce the incidence and mortality of cervical cancer in India. Periodic screening (irrespective of the method used) and follow-up evaluation of women 30 years of age or more are acceptable and are the cost-effective approaches to prevent cervical cancer. A Pap smear is a cytological test designed to detect abnormal cervical cells. The low sensitivity of a single Pap test makes it necessary to screen women relatively frequently, every 3-5 years [24]. The conventional papanicolaou smear (CPS) has been the mainstay of screening for cervical cancer and its precursor lesions for approximately 50 years without major changes in the techniques related to preparation and interpretation. Despite its success as a preventive screening tool for cervical cancer, CPS has its limitations [25]. Conventional cytology (CC) is a very good method for cervical cancer screening as it needs non-expensive equipment for processing and evaluation, which is suitable for the developing countries that have a very limited resource. Several studies reported the advantage of LBC over CC and suggested to convert from CC to LBC. However, there are various studies that have indicated the similar sensitivity and specificity of these two methods. Besides the advantages of LBC like reducing the obscuration and smaller area to be evaluated, the most striking benefit of LBC is the ability to perform further tests such as HPV testing from the residual specimen. Currently, LBC is cheaper than in the past and hence it is possible to be used as a routine service in developing country [26]. A decline in the incidence and mortality caused by cervical cancer has been observed in the past few decades as a result of screening by cytology. In recent years, the accuracy of the conventional Pap smear has come under a great deal of scrutiny [27]. Liquid-based cytology (LBC) was introduced in mid-1990s as an alternative technique to process cervical samples. Since then a lot of countries in the Western world has switched from conventional Pap smear method to LBC, although amid contrasting results from various studies comparing the benefits of LBC with CPS [28].

Pathology Update: Tropical Journal of Pathology \& Microbiology Available online at: www.medresearch.in 722 | P a g e 


\section{Original Research Article}

We compared the parameters we had derived from our study with some standard studies and analysed it statistically. In the present study the most common age group that have undergone the testing was $4^{\text {th }}$ decade which is comparable with Hawaldar [29] and Sherwani [10] whereas the study by Garg [27] showed less than 30 years age group as the most common (Table-4).

Table-4: Age incidence

\begin{tabular}{|c|c|c|c|c|}
\hline Age group & Hawaldar R 2016 [29] & Garg V 2016 [27] & Sherwani RK 2007 [10] & Present study \\
\hline$<30$ & 28.9 & 56.96 & 31.26 & 31 \\
\hline $31-40$ & 37.6 & 33.90 & 48.13 & 38 \\
\hline $41-50$ & 16.3 & 9.14 & 11.86 & 21 \\
\hline$>50$ & 4.3 & --- & 8.75 & 10 \\
\hline
\end{tabular}

The most common clinical presentation of discharge PV (46\%) was comparable with the studies by Garg and Sherwani (Table-5).

Table-5: Clinical presentation

\begin{tabular}{|l|c|c|c|}
\hline & Garg V 2016 [27] & Sherwani RK 2007 [10] & Present study \\
\hline Discharge PV & 48.40 & 42.5 & 46 \\
\hline Lower abdominal pain & 32.90 & 27.5 & 42 \\
\hline Post coital bleeding & 3.00 & --- & 11 \\
\hline Irregular menstruation & --- & 23.8 & 21 \\
\hline
\end{tabular}

The time taken to screen the entire CPS slide was more compared to the same in a LBC slide and the results were comparable with other studies like Sharma J [30] and Singh VB [28] that also have shown LBC to be superior to CPS in time consumed for screening (Table-6).

Table-6: Screening time - CPS vs LBC

\begin{tabular}{|l|c|c|c|}
\hline & Sharma J 2016 [30] & Singh VB 2015 [28] & Present study \\
\hline CPS & $4 \mathrm{mins}$ & $5-6 \mathrm{mins}$ & $6-7 \mathrm{mins}$ \\
\hline LBC & $2 \mathrm{mins}$ & $2.5-3 \mathrm{mins}$ & $3-4 \mathrm{mins}$ \\
\hline
\end{tabular}

Many studies were comparable with the present study as far as the unsatisfactory rate is considered and all the studies unanimously showed less number of unsatisfactory smears in LBC than in CPS (Table-7). The most common reason for the unsatisfactory smear is insufficient cell count in both CPS and LBC and the same is comparable with studies by Singh VB, Gupta N [31], Jeong H [32] (Table-8). The second common reason for unsatisfactory smear in present study is inflammatory cells obscuring the epithelial cell morphology.

Table-7: Unsatisfactory rate - CPS vs LBC

\begin{tabular}{|l|c|c|}
\hline & CPS & LBC \\
\hline Sharma J 2016 [30] & $8 \%$ & 7 \\
\hline Singh VB 2015 [28] & 4.3 & 1.7 \\
\hline Gupta N 2016 [31] & 10.5 & 3.2 \\
\hline Sherwani RK 2007 [10] & 5 & 1.26 \\
\hline Jeong H 2017 [32] & 3.31 & 0 \\
\hline Nishio H 2018 [33] & 0.3 & 1.7 \\
\hline Costa MOLP 2015 [34] & 4.4 & $3 \%$ \\
\hline Present study & $5 \%$ & \\
\hline
\end{tabular}

Table-8: Insufficient cell count as a reason for unsatisfactory smear - CPS vs LBC

\begin{tabular}{|l|c|c|}
\hline & CPS & LBC \\
\hline Singh VB 2015 [28] & 37.2 & 58.8 \\
\hline Gupta N 2016 [31] & 31.4 & 29.3 \\
\hline
\end{tabular}




\begin{tabular}{|l|c|c|}
\hline \multicolumn{3}{|c|}{ Original Research Article } \\
\hline Jeong H 2017 [32] & 37.2 & 58.8 \\
\hline Present study & 41.3 & 61.4 \\
\hline
\end{tabular}

The percentage of slides that showed inflammation is $77 \%$ in CPS and $72 \%$ in LBC. The studies by Sharma J, Garg V and Costa (Table-9) all showed similar results thereby making LBS to be superior to CPS as far as the background is considered as dense inflammation may sometimes be the reason for unsatisfactory smear because it can obscure the cell morphology.

Table-9: Inflammation seen - CPS vs LBC

\begin{tabular}{|c|c|c|}
\hline & CPS & LBC \\
\hline Sharma J 2016 [30] & $96 \%$ & 92 \\
\hline Garg V 2016 [28] & 85.54 & 46.5 \\
\hline Costa MOLP 2015 [34] & $58.5 \%$ & 46.5 \\
\hline Present Study & 77 & 72 \\
\hline
\end{tabular}

Table-10: Normal study - CPS vs LBC

\begin{tabular}{|l|c|c|c|c|}
\hline & Singh VB 2015 [28] & Sherwani RK 2007 [10] & Costa MOLP 2015 [34] & Present study \\
\hline CPS & 54.3 & 85 & 34.7 & 86 \\
\hline LBC & 63.9 & 73.8 & 48.8 & 80 \\
\hline
\end{tabular}

Coming onto the presence of organisms CPS picked up six cases of bacterial vaginosis and three cases of candida in contrast to LBC which was able to pick up only five and two cases of bacterial vaginosis and candida respectively. The results are comparable with Sharma J and Garg V whose studies also show CPS to be slightly superior in picking up the organisms (Table-11).

Table-11: Organisms present - CPS vs LBC

\begin{tabular}{|l|c|c|c|c|}
\hline \multirow{2}{*}{ BV } & & Sharma J 2016 [30] & Garg V 2016 [28] & Present study \\
& CPS & 29 & 12.1 & 06 \\
\cline { 2 - 5 } & LBC & 28 & 11.2 & 05 \\
\hline \multirow{2}{*}{ Candida } & CPS & 12 & 2.8 & 03 \\
\cline { 2 - 5 } & LBC & 09 & 1.2 & 02 \\
\hline
\end{tabular}

The last of the parameter epithelial cell abnormalities also did not do great favour for LBC because again CPS was slightly superior to LBC which showed epithelial abnormality in total of 8 cases in contrast to CPS which showed the same in 9 cases. This is in contrast to some studies which showed LBC slightly better (Table-12).

Table-12: Epithelial cell abnormalities - CPS vs LBC

\begin{tabular}{|c|c|c|c|c|c|}
\hline & & Sharma J 2016 [30] & Sherwani RK 2007 [10] & $\begin{array}{c}\text { Nishio H 2018 } \\
{[33]}\end{array}$ & Present study \\
\hline \multirow{2}{*}{ LSIL } & CPS & 0.71 & 10.6 & 9.3 & 3 \\
\cline { 2 - 6 } & LBC & 0.71 & 18.2 & 13.1 & 3 \\
\hline \multirow{2}{*}{ ASCUS } & CPS & 0.71 & --- & 14.5 & 4 \\
\cline { 2 - 6 } & LBC & --- & --- & 11.5 & 3 \\
\hline \multirow{2}{*}{ HSIL } & CPS & 0.71 & 0.6 & 46.9 & 1 \\
\cline { 2 - 6 } & LBC & 0.71 & 4.3 & 44.9 & 1 \\
\hline \multirow{2}{*}{ ASC-H } & CPS & 0.71 & ---0 & 11.9 & 1 \\
\cline { 2 - 6 } & LBC & --- & --- & 8.9 & 1 \\
\hline
\end{tabular}

Limitations: Since sample was taken twice from the same patient for two different techniques, the sample amount available for both the techniques was low in some cases. Some patients were not co-operative for the sample to be taken for the second time.

\section{Conclusion}

In our study LBC offered some advantages like lesser screening time and cleaner background compared to 


\section{Original Research Article}

CPS and LBC in general provides us with the opportunity to prepare duplicate slides, cell-block preparations from residual sample as well as HPV testing option. But still CPS provides one important advantage of cost efficacy which is a very important factor in a set up like ours. In addition to that, the detection rate of organisms or epithelial cell abnormality also remained same between the two. Above all we should keep in mind that there is no synchronised initiative from public health authorities for prevention and control of cancer cervix in India which show alarming statistics. Therefore our main aim should be towards creating awareness among the rural setup like ours and high cost of LBC will be a main hindrance for it. So to conclude, even though LBC is slightly superior to CPS as far as the quality of smear is concerned, taking into consideration the similar detection rate of other parameters in addition to the cost efficacy CPS provides, it is better to continue with CPS as our setup is a rural setup with low resource setting.

\section{What this study adds to existing knowledge?}

This study cast light on the importance of creating awareness among rural population about cancer cervix as well as the effective screening programme (CPS) that is available at an affordable cost. Also to the best of author's knowledge this study was the first of its kind in such a rural setup of Tamilnadu.

\section{Author's contribution}

Dr. Gowri Sankar Ramalingam: Contributed in collecting the data, compiling it, preparing the manuscript and reviewing the slides.

Dr. R. Thamil Selvi: Helped in reviewing slides and approving the final version.

Dr. Anbu Lenin Kulandaivel: Author helped in editing the manuscript and final review.

Dr. M. Poornima: Contributed in retrieving some clinical details and manuscript editing.

Findings: Nil; Conflict of Interest: None initiated Permission from IRB: Yes

\section{References}

1. Ferlay J, Soerjomataram I, Dikshit R, Eser S, Mathers C, Rebelo M, Can Int J Cancer. 2015;136(5):E359-E386. doi: 10.1002/ijc.29210.

2. Forouzanfar MH, Foreman KJ, Delossantos AM, Lozano R, Lopez AD, Murray CJ, Breast and cervical cancer in 187 countries between 1980 and 2010: a systematic analysis. Lancet. 2011;378(9801):1461-
1484. doi: 10.1016/S0140-6736(11)61351-2. Epub 2011 Sep 14.

3. World Health Organization, Cancer, Cervical cancer. Available from https://www.who.int/cancer/cervicalcancer

4. Babes A. Diagnostic du cancer du col utérin par les frottis. Presse Medicale 1928;36:451-454.

5. Classes in oncology: George Nicholas Papanicolaou's new cancer diagnosis presented at the Third Race Betterment Conference, Battle Creek, Michigan, January 2-6, 1928, and published in the Proceedings of the Conference. CA Cancer J Clin. 1973;23(3):174-179. doi: https://doi.org/10.3322/canjclin.23.3.174

6. Papanicolaou GN, Traut HF. The diagnostic value of vaginal smears in carcinoma of the uterus. 1941. Arch Pathol Lab Med. 1997;121(3):211-224.

7. Papanicolaou GN. Atlas of exfoliative cytology. Atlas of exfoliative Cytol. 1954.

8. McSweeney DJ, McKay DG. Uterine cancer: its early detection by simple screening methods. N Engl J Med 1948;238(25):867-870.

9. Janicek MF, Averette HE. Cervical cancer: prevention, diagnosis, and therapeutics. CA Cancer $\mathrm{J}$ Clin. 2001;51(2):92-114. doi: 10.3322/canjclin.51.2.92

10. Sherwani RK, Khan T, Akhtar K, Zeba A, Siddiqui FA, Rahman K, Afsan N. Conventional Pap smear and liquid based cytology for cervical cancer screening-A comparative study. J Cytol. 2007;24(4):167-172.

11. Nandini NM, Nandish SM, Pallavi P, Akshatha SK, Chandrashekhar AP, Anjali S. Manual liquid-based cytology in primary screening for cervical cancer--a cost effective preposition for scarce resource settings. Asian Pac J Cancer Prev. 2012;13(8):3645-3651. doi: 10.7314/apjcp.2012.13.8.3645

12. Abulafia O, Pezzullo JC, Sherer DM. Performance of ThinPrep liquid-based cervical cytology in comparison with conventionally prepared Papanicolaou smears: a quantitative survey. Gynecol Oncol. 2003;90(1):137-144. doi: 10.1016/s00908258(03)00176-8

13. Zhu J, Norman I, Elfgren K, Gaberi V, Hagmar B, Hjerpe A, A comparison of liquid-based cytology and Pap smear as a screening method for cervical cancer. Oncol Rep. 2007;18(1):157-160. doi: https://doi.org/10.3892/or.18.1.157 
14. Siebers AG, Klinkhamer PJ, Grefte JM, Massuger LF, Vedder JE, Beijers-Broos A, Comparison of liquidbased cytology with conventional cytology for detection of cervical cancer precursors: a randomized controlled trial. JAMA. 2009;302(16):1757-1764. doi: 10.1001/jama.2009.1569.

15. Confortini M, Bulgaresi P, Cariaggi MP, Carozzi FM, Cecchini S, Cipparrone I, et al. Conventional pap smear and liquid-based cervical cytology smear: comparison from the same patient. Tumori. 2002;88(4):288-290.

16. Mallath MK, Taylor DG, Badwe RA, Rath GK, Shanta V, Pramesh CS, et al. The growing burden of cancer in India: epidemiology and social context. Lancet Oncol. 2014;15(6):e205-e212. doi: 10.1016/S1470-2045(14)70115-9. Epub 2014 Apr 11.

17. Lazcano-Ponce E, Alonso P, Ruiz-Moreno JA, Hernández-Avila M. Recommendations for cervical cancer screening programs in developing countries: The need for equity and technological development. salud pública de méxico. 2003;45(3):449-462.

18. Bernstein SJ, Sanchez-Ramos L, Ndubisi B. Liquidbased cervical cytologic smear study and conventional Papanicolaou smears: a metaanalysis of prospective studies comparing cytologic diagnosis and sample adequacy. Am J Obstet Gynecol. 2001;185(2):308-317. doi: $10.1067 / \mathrm{mob} .2001 .116736$

19. Bibbo M, Wilbur DC, editors. Comprehensive cytopathology. $3^{\text {rd }}$ ed. China: Elsevier saunders; 2008.

20. Sankaranarayanan R, Budukh AM, Rajkumar R. Effective screening programmes for cervical cancer in low- and middle-income developing countries. Bull World Health Organ. 2001;79(10):954-962. Epub 2001 Nov 1.

21. Murthy NS, Chaudhry K, Saxena S. Trends in cervical cancer incidence--Indian scenario. Eur J Cancer Prev. 2005;14(6):513-518.

22. Joshi S, Sankaranarayanan R. Opportunities for cervical cancer prevention in India. J Kris Inst Med Sci Universi 4(1):8-17.

23. Eddy DM. Secondary prevention of cancer: an overview. Bull World Health Organ. 1986;64(3):421429.

24. Pankaj S, Nazneen S, Kumari S, Kumari A, Kumari A, Kumari J, et al. Comparison of conventional Pap smear and liquid-based cytology: A study of cervical cancer screening at a tertiary care center in Bihar.

\section{Original Research Article}

Indian J Cancer. 2018;55(1):80-83. doi: 10.4103/ijc.IJC_352_17.

25. Deshou H, Changhua W, Qinyan L, Wei L, Wen F. Clinical utility of Liqui-PREPTM cytology system for primary cervical cancer screening in a large urban hospital setting in China. J Cytol/Indian Acad Cytol. 2009;26(1):20-25.

26. Kituncharoen S, Tantbirojn $\mathrm{P}$, Niruthisard $\mathrm{S}$. Comparison of unsatisfactory rates and detection of abnormal cervical cytology between conventional Papanicolaou smear and liquid-based cytology (Sure Path (R)). Asian Pac J Cancer Prev. 2015;16(16):84918494. doi: 10.7314/apjcp.2015.16.18.8491.

27. Garg V, Thakral RK, Sharma VK, Agarwal AK, Gupta K, Vedi A. Conventional pap (papanicoloau) smear cytology in primary screening of cervical lesions $\&$ its comparison with manual liquid-based cytology. Indian J Pathol Oncol. 2016;3(3):485-490. doi: 10.5958/2394-6792.2016.00090.9

28. Singh VB, Gupta N, Nijhawan R, Srinivasan R, Suri $\mathrm{V}$, Rajwanshi A. Liquid-based cytology versus conventional cytology for evaluation of cervical Pap smears: experience from the first 1000 split samples. Indian J Pathol Microbiol. 2015;58(1):17-21. doi: 10.4103/0377-4929.151157.

29. Ranjana H, Sadhna S. Comparison of conventional pap smear versus liquid based cytology in a diagnostic centre of central Madhya Pradesh. Indian J Pathol Oncol. 2016;3(1):42-47. doi:10.5958/23946792.2016.00010.7.

30. Sharma J, Toi PCh, Siddaraju N, Sundareshan M, Habeebullah S. A comparative analysis of conventional and SurePath liquid-based cervicovaginal cytology: A study of 140 cases. J Cytol. 2016;33(2):80-84. doi: 10.4103/0970-9371.182525.

31. Gupta N, Bhar VS, Rajwanshi A, Suri V. Unsatisfactory rate in liquid-based cervical samples as compared to conventional smears: A study from tertiary care hospital. Cyto J. 2016;13:14. doi: 10.4103/17426413.183831. eCollection 2016.

32. Jeong H, Hong SR, Chae SW, Jin SY, Yoon HK, Lee J. Comparison of Unsatisfactory Samples from Conventional Smear versus Liquid-Based Cytology in Uterine Cervical Cancer Screening Test. J Pathol Transl

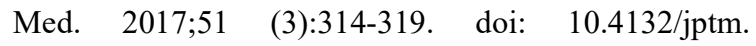
2017.03.17. Epub 2017 Apr 17.

33. Nishio $H$, Iwata $T$, Nomura $H$, Morisada $T$, Takeshima N, Takano H et al. Liquid-based cytology 


\section{Original Research Article}

versus conventional cytology for detection of uterine cervical lesions: a prospective observational study. Jap J Clin Oncol. 2018;48(6):522-528. doi: 10.1093/jjco/ hyy050.

Papanicolaou cytology samples with liquid-based cervical cytology samples from women in Pernambuco, Brazil. Braz J Med Biol Res. 2015;48(9):831-838. doi:10.1590/1414-431X20154252.

34. Costa MO, Heráclio SA, Coelho AV, Acioly VL, Souza PR, Correia MT. Comparison of conventional

\section{How to cite this article?}

Gowri R S, Thamil R S, Anbu K L, M. Poornima. Good old pap smear towers over the latest LBC for cervical screening: a study in a rural teaching institute of Tamil Nadu, India. Trop J Path Micro 2019;5(9):719727.doi:10.17511/jopm.2019.i09.17. 